\begin{tabular}{|l|l|l||}
\hline \multicolumn{2}{|c|}{ PublisherInfo } \\
\hline \hline PublisherName & $:$ & BioMed Central \\
\hline \hline PublisherLocation & $:$ & London \\
\hline \hline PublisherImprintName & $:$ & BioMed Central \\
\hline \hline
\end{tabular}

\title{
Genetics of social behaviour
}

\begin{tabular}{|l|l|l||}
\hline \multicolumn{2}{|c|}{ ArticleInfo } \\
\hline \hline ArticleID & $:$ & 4254 \\
\hline \hline ArticleDOI & $:$ & $10.1186 /$ gb-spotlight-20011116-01 \\
\hline \hline ArticleCitationID & $:$ & spotlight-20011116-01 \\
\hline \hline ArticleSequenceNumber & $:$ & 325 \\
\hline \hline ArticleCategory & $:$ & Research news \\
\hline ArticleFirstPage & $:$ & 1 \\
\hline \hline ArticleLastPage & $:$ & 2 \\
\hline \hline & $:$ & RegistrationDate : 2001-11-16 \\
ArticleHistory & $:$ & OnlineDate \\
\hline \hline ArticleCopyright & $:$ & BioMed Central Ltd2001 \\
\hline \hline ArticleGrants & $:$ & \\
\hline \hline ArticleContext & $:$ & 130592211 \\
\hline \hline
\end{tabular}




\section{Jonathan B Weitzman}

Email: jonathanweitzman@hotmail.com

Social behaviour can be pretty complex at the best of times, and defining the underlying genetic events has provided a formidable challenge. In the November 15 Sciencexpress, Michael Krieger and Kenneth Ross, from the University of Georgia, describe the first clear example of a single gene affecting complex social behaviour (ScienceXpress 10.1126/science.1065247). Colony queen number in the fire ant Solenopsis invicta is associated with variations in the $G p-9$ gene, such that worker ants with the $B$ allele are associated with a single queen (monogyne social form), whereas the $b$ allele workers are polygyne. Krieger and Ross sequenced the $G p-9$ gene and show that it encodes a pheromone-binding protein. Thus, GP-9 may play a role in chemoreception by influencing worker recognition and acceptance of pheromone-producing queens. The $B$ and $b$ alleles are distinguished by several amino-acid changes. The Gp-9 allele variation is conserved in South American fire ants exhibiting social polymorphism. This study provides fascinating insights into the genetic basis and evolution of complex social behaviour.

\section{References}

1. Sciencexpress, [http://www.sciencexpress.org]

2. University of Georgia, [http://www.uga.edu]

3. Genetic control of social organization in an ant

4. Do pheromone binding proteins converge in amino acid sequence when pheromones converge? 